\title{
BIOACTIVE COMPOUNDS AND ANTIOXIDANT ACTIVITY OF PINEAPPLE FRUIT OF DIFFERENT CULTIVARS ${ }^{1}$
}

\author{
ESTER ALICE FERREIRA ${ }^{2}$, HELOISA ELIAS SIQUEIRA $^{3}$, EDUARDO VALERIO VILAS BOAS $^{4}$, \\ VANESSA STAHL HERMES ${ }^{5}$, ALESSANDRO DE OLIVEIRA RIOS ${ }^{6}$
}

\begin{abstract}
Pineapple is widely consumed and appreciated not only due to its taste and aroma, and also to its nutritional, functional and antioxidant properties, including its vitamin $\mathrm{C}$ and carotenoid contents. Brazil is one of the largest world' pineapple producer, and Pérola and Smooth Cayenne cultivars are the most commonly grown and marketed, but their susceptibility to fusariosis can compromise cultivation. New cultivars resistant to this pathogen are available to meet the demands of pineapple producers and consumers. The aim of this study was to evaluate the content of bioactive compounds and antioxidant activity of pineapple fruits of Imperial, Victoria, IAC Fantástico and Gomo de Mel cultivars, as well as traditional Pérola and Smooth Cayenne cultivars. Fruits grown in the Triângulo Mineiro region were evaluated by colorimetry, determination of ascorbic acid and phenolic compounds by spectrometry, antioxidant activity by ABTS and carotenoid profile by HPLC. Regarding color, Gomo de Mel cultivar showed lower brightness and higher value of parameter $b^{*}$, indicating a more intense yellow color in this fruit. This result is consistent with the highest carotenoid concentration in this cultivar. Another cultivar that stood out was Imperial, which, while maintaining high carotenoid levels, also showed high concentrations of vitamin $\mathrm{C}$ and phenolic compounds, and higher antioxidant activity. Victoria cultivar showed low levels of bioactive compounds and antioxidant activity, even lower than IAC Fantástico cultivar, which showed levels of bioactive compounds similar to traditional Pérola and Smooth Cayenne cultivars.
\end{abstract}

Index terms: Ananas comosuse, fusariosis, vitamin C, phenolics, carotenoids.

\section{COMPOSTOS BIOATIVOS E ATIVIDADE ANTIOXIDANTE DE FRUTOS DE CULTIVARES DE ABACAXIZEIROS}

RESUMO-O abacaxi é um fruto muito consumido e apreciado não só pelo sabor e aroma, mas também pelas propriedades nutricionais, funcionais e antioxidantes, incluindo os teores de vitamina $\mathrm{C}$ e carotenoides. O Brasil é um dos principais produtores de abacaxi, sendo as cultivares Pérola e Smooth Cayenne as mais plantadas e comercializadas, porém sua suscetibilidade à fusariose pode comprometer o cultivo. Novas cultivares resistentes a este patógeno estão sendo disponibilizadas no mercado, buscando atender às demandas do produtor e do mercado consumidor. Objetivou-se avaliar compostos bioativos e atividade antioxidante de frutos de cultivares de abacaxizeiros cultivados na região do Triângulo Mineiro. Os frutos foram avaliados quanto à colorimetria, quantificação de ácido ascórbico e fenólicos totais por espectrometria, atividade antioxidante por ABTS e perfil de carotenoides por HPLC. Em relação à coloração, a cultivar Gomo-de-Mel apresentou menor luminosidade e maior valor do parâmetro $b^{*}$, indicando coloração mais amarela do fruto. Esse resultado é condizente pela maior concentração de carotenoides nessa cultivar. Outra cultivar que se destacou foi a Imperial, que, além de apresentar altos teores de carotenoides, demonstrou também elevadas concentrações de vitamina $\mathrm{C}$ e compostos fenólicos, bem como maior atividade antioxidante. A cultivar Vitória apresentou baixos teores de compostos bioativos e atividade antioxidante, inferiores à IAC, Fantástico que apresentou níveis de compostos bioativos similares às cultivares tradicionais Pérola e Smooth Cayenne. Termos para indexação: Ananas comosus, fusariose, vitamina $\mathrm{C}$, fenólicos, carotenoides.

\footnotetext{
${ }^{1}$ (Trabalho 083-15). Recebido em: 18-03-2015. Aceito para publicação em: 23-10-2015. Finnancial support FAPEMIG.

${ }^{2}$ Agronomist, DSc, Researcher at the Agricultural Research Company of Minas Gerais - Sul de Minas Regional Unit. Research productive grant of FAPEMIG. E-mail: ester@epamig.br

${ }_{3}^{3}$ Agronomist, DSc, Post-doctoral student, Department of Food Science, Federal University of Lavras. E-mail: heloisa.elias@yahoo. com.br

${ }^{4}$ Agronomist, DSc, Associate Professor IV Department of Food Science, Federal University of Lavras. E-mail: evbvboas@dca.ufla.br ${ }_{5}^{5}$ Biomedic, DSc, Post-doctoral student, Department of Food Science, Federal University of Rio Grande do Sul. E-mail: van.hermes@gmail.com ${ }^{6}$ Agronomist, DSc, Associate Professor I Department of Food Science, Federal University of Rio Grande do Sul. E-mail; alessandro. rios@ufrgs.br
} 


\section{INTRODUCTION}

Brazil is one of the largest pineapple producers and consumers (Ananas comosus), which is one of the most popular tropical fruits, appreciated not only for its taste, juiciness and texture, but also to the high levels of vitamin C, carotenoids and fibers (PAULL; CHEN, 2003; BENÍTEZ et al., 2012; VIANA et al., 2013).

Pérola cultivar is predominant in pineapple cultivation in Brazil, which is usually consumed fresh, and Smooth Cayenne, which has higher consumption after processing. The susceptibility of these cultivars to Fusarium guttiforme (syn. F. subglutinans f. Sp. Ananas), which causes fusariosis, is responsible for major losses during cultivation (VENTURA et al., 2009).

Seeking to increase the supply of pineapple fruits in the Brazilian market in the late 90s, Chinese cultivar called "Gomo-de-Mel" or "Abacaxi-deGomo" was introduced in Brazil. Despite being susceptible to fusariosis, this cultivar differs from the others for its sweetness and ripeness, and fruitlets are less attached and can be detached in the form of berries (USBERTI FILHO, 1999).

However, due to the susceptibility to fusariosis, pineapple has been the subject of breeding programs that culminated with the release of new cultivars resistant to this disease such as Imperial cultivars produced by EMBRAPA Mandioca e Fruticultura (CNPMF); Vitória by INCAPER, and IAC Fantástico by IAC (MAPA, 2004; INCAPER, 2006; IAC, 2010).

In addition to disease resistance in this culture, one of the important characteristics of pineapple tree refers to the nutritional properties of fruits. Pulp coloration, for example, is related to the carotenoid content, $\beta$-carotene being responsible for about $35 \%$ of total pigments (RAMSAROOP; SAULO, 2007). $\beta$-carotene, $\alpha$-carotene and cryptoxanthin stand out for their provitamin A activity, being converted into vitamin A or retinol after ingestion. Furthermore, carotenoids have antioxidant action, protecting cells and tissues from damage caused by free radicals, strengthening the immune system and inhibiting the development of certain types of cancers (ZEB; MEHMOOD, 2004).

Pineapple fruits also exhibit high levels of other antioxidants such as phenolic compounds and vitamin C (HOSSAIN; RAHMAN, 2011; RAMALLO; MASCHERONI, 2012). Phenolic compounds responsible for bitterness, astringency, flavor, color and oxidative stability of fruits and vegetables have shown an effect in health protection, with not only antioxidant activity by scavenging free radicals, but also inhibition of hydrolytic and oxidative enzymes and anti-inflammatory functions in human cells (NACZK; SHAHIDI, 2004). Vitamin $\mathrm{C}$ is a natural antioxidant that can inhibit the development of serious clinical conditions such as heart disease and some types of cancers. Unlike phenolic compounds that are quickly metabolized, vitamin $\mathrm{C}$ has high bioavailability, and is therefore one of the most important antioxidant in cells, acting as scavenger of reactive oxygen species (ROS). Thus, vitamin $\mathrm{C}$ can protect membranes and lipoproteins from oxidative damage (SIES; STAHL, 1995; GARDNER et al., 2000).

Among the existing pineapple cultivars, Vitória, Gomo-de-Mel and Imperial have already been studied in various regions of Brazil with regard to sensory acceptance and physicochemical characterization of fruits (CUNHA et al., 2007; BRITO et al., 2008; BERILLI et al., 2011; RAMOS et al., 2010). However, there are no scientific reports on the content of bioactive compounds in fruits of these cultivars.

Since pineapple is highly nutritious due to its high levels of vitamin $C, \beta$-carotene and phenolic compounds (KONGSUWAN et al, 2009; HOSSAIN; RAHMAN, 2011), this study aimed to evaluate bioactive compounds and antioxidant activity of pineapple fruits of different cultivars.

\section{MATERIAL AND METHODS}

Pineapple fruits of Imperial, Vitória, IAC Fantástico, Gomo-de-Mel cultivars were evaluated, as well as traditional Pérola and Smooth Cayenne cultivars cultivated in the municipality of Canápolis, located in the Triangulo Mineiro region, located at $19^{\circ} 39^{\prime} 19$ 'S and $47^{\circ} 57$ ' 27 'W and $795 \mathrm{~m}$ asl, with average annual rainfall of $1,600 \mathrm{~mm}$, average annual temperature of $22.6^{\circ} \mathrm{C}$ and average relative air humidity of $68 \%$. The local climate is classified as hot tropical (AW), according to the Köppen classification.

Cultivars were implemented on January 2010 , with management and cultural practices recommended for the culture. Fruit maturation occurred in September 2012, and fruits were harvested when showing $75 \%$ of yellow bark or with color characteristic of maturation. Harvested fruits were packed in cardboard boxes and immediately transported to the Laboratory of Fruits and Vegetables of the Department of Food Science, Federal University of Lavras (UFLA).

The determination of the fruit pulp coloring 
considered five distinct aspects using Minolta colorimeter model CR-400, being determined in the CIE- $\mathrm{L} * \mathrm{a} * \mathrm{~b} *$ mode, where $\mathrm{L} *$ indicates brightness, $\mathrm{a} *$ indicates coloration from green $(-)$ to red $(+)$ and $\mathrm{b} *$ indicates coloration from blue (-) to yellow $(+)$.

Ascorbic acid was determined by the colorimetric method (after oxidation to dehydroascorbic acid), using 2,4-dinitrophenylhydrazine, according to Strohecker and Henning (1967), with results expressed in $\mathrm{mg}$ ascorbic acid / $100 \mathrm{~g}$ pulp.

The analysis of total phenolics followed the Waterhouse technique (2002), and extraction adapted of Larrauri et al. (1997), with extract directly evaluated in a spectrophotometer using the Folin-Ciocalteu method as AOAC (2005); and results expressed in mg of gallic acid / $100 \mathrm{~g}$ pulp. The antioxidant activity followed the methodology of Rufino et al. (2007) and extraction adapted of Larrauri et al. (1997). The calculation was based on the formula: $\% \mathrm{SRL}=$ Absorbance of control Absorbance of sample / Absorbance of control x100.

Frozen pulp samples of different cultivars were sent to the Laboratory of Bioactive Compounds of the Federal University of Rio Grande do Sul (UFRGS) for analysis of the carotenoid profile. The extraction of pigments was carried out according to Mercadante and Rodriguez-Amaya (1998) using acetone, followed by saponification with $10 \% \mathrm{KOH}$ in methanol overnight at room temperature. After alkali removal, the extract was concentrated in rotaevaporator (Fisatom, Uberlândia, Minas Gerais, Brazil) $\left(\mathrm{T}<35^{\circ} \mathrm{C}\right)$, dried in nitrogen flow and stored in freezer for later quantification by high performance liquid chromatography (HPLC) in equipment with degasser, quaternary solvent pump and UV / vis detector. The column used was polymeric reversed phase C30 (250mm x $4.6 \mathrm{~mm}$ i.d., $3 \mu \mathrm{m}$ ) (YMC). The mobile phase consisted of water / methanol / methyl tert-butyl ether (MTBE) (J.T. Baker, Mallinckrodt), starting with ratios of 5: $90: 5$, reaching $0: 95: 5$ in 12 min, 0:89:11 in $25 \mathrm{~min}, 0: 75: 25$ in $40 \mathrm{~min}$ and finally 0:50:50 after $60 \mathrm{~min}$, with flow rate of $1 \mathrm{ml} / \mathrm{min}$ at $33^{\circ} \mathrm{C}$ (ZANATTA; MERCADANTE, 2007). For quantification, standard curves of $\beta$-carotene $(5-50 \mu \mathrm{g}$ / ml) (Sigma-Aldrich, Cas Number 7235-40-7), and lutein (1-65 $\mu \mathrm{g} / \mathrm{ml}$ ) (Indofine Chemical Company, Cas Number 127-40-2) were constructed. The limits of quantification (LOQ) and detection (LOD) were respectively $10.89 \times 10^{-2} \mathrm{mg} / \mathrm{kg}$ and $6.53 \times 10^{-2} \mathrm{mg}$ / $\mathrm{kg}$ for B-carotene and $1.15 \times 10^{-2} \mathrm{mg} / \mathrm{kg}$ and 6.9 x $10^{-3} \mathrm{mg} / \mathrm{kg}$ for lutein.

The design was completely randomized, having the different cultivars as treatments. To evaluate the characteristics under study, statistical analysis was performed in the R statistical software (R Development Core Team, 2013), with the aid of the ExpDes package. Data were submitted to the Shapiro-Wilk normality test and the averages were compared by the Scott_Knott test at 5\% probability.

\section{RESULTS AND DISCUSSION}

Regarding the pulp color of fruits of different pineapple cultivars, it was observed that the a * values for fruits of different cultivars analyzed showed no significant difference (Table 1). For the other parameters, Gomo-de-Mel cultivar showed lower brightness and higher $\mathrm{b} *$ value, indicating more yellowish color when compared to the other cultivars. The highest brightness was observed for Imperial cultivar, which showed no significant difference in $b *$ values in relation to IAC Fantástico and Smooth Cayenne cultivars. Pérola and Vitória cultivars showed lower $\mathrm{b} *$ values, indicating less yellowish color when compared to the other cultivars.

The brightness values found are in agreement with $L^{*}$ values presented by Viana et al. (2013) for Pérola, Smooth Cayenne and Vitória cultivars (respectively 76.77, 77.66 and 73.53). However, the same author found $\mathrm{L} *$ value of 60.20 for Imperial cultivar, indicating that this cultivar is the darkest among cultivars, while in the present study, this variety had the highest $L *$ value (77.79), proving to be the clearest cultivar. Ramsaroop and Saulo (2007) observed lower values not only for the brightness of Smooth Cayenne fruits (46.2), but also for parameter $\mathrm{b} *(15.5)$.

The results of color parameters, indicating that Gomo-of-Mel and Imperial cultivars showed more yellowish color, are consistent with the results quantifying the carotenoid contents. These antioxidant compounds are responsible for colors ranging from yellow to red in many fruits and vegetables (ZEB; MEHMOOD, 2004), and in pineapple fruits, the higher carotenoid contents, the more yellow is the fruit (RAMSAROOP; SAULO, 2007).

The cultivar presenting the highest carotenoid contents was Gomo-de Mel (Figure 1), which also showed greater yellow color values. Among carotenoids, $\alpha$-carotene showed the highest concentration, and its concentration was higher in fruits of Gomo-de-Mel cultivar, followed by Imperial cultivar. These two cultivars also showed high cryptoxanthin concentrations, with values greater than twice that found in other cultivars. The lutein concentration was also high in these two cultivars. However, $\beta$-carotene showed higher 
concentration in IAC Fantástico cultivar, but without significant differences from Gomo-de-Mel and Imperial cultivars. Zeaxanthin showed low concentration for all pineapple cultivars, even though for IAC Fantástico and Smooth Cayenne cultivars, these values were higher than the $\alpha$-carotene concentration. Vitória and Pérola cultivars showed lower concentrations for all carotenoids, and in Pérola cultivar, zeaxanthin and $\alpha$-carotene were not detected.

Concerned about vitamin A deficiency in the population, Setiawan et al. (2001) investigated the carotenoid content of some Indonesian fruits, since these compounds are precursors of this vitamin. Quantifying cryptoxanthin and $\beta$-carotene, they found, respectively, 89 and $230 \mathrm{mg} / 100 \mathrm{~g}$ in pineapple fruits. This cryptoxanthin content was similar to that found in the present work for Smoot Cayenne cultivar and lower than values found for Gomo-de-Mel and Imperial cultivars. The $\beta$-carotene content reported for Indonesian fruits was higher than all cultivars evaluated in this study. Moreover, Kongsuwan et al. (2009) found lower $\beta$-carotene levels for two Thai pineapple varieties, Phulae and Nanglae (3.35 and $1.41 \mu \mathrm{g} / 100 \mathrm{~g}$, respectively), while another study with Thai fruits did not detect $\beta$-carotene in pineapple fruits (CHAROENSIRI et al., 2009).

Viana et al. (2013) quantified only the total carotenoid content, and for Imperial cultivar, the content found was $266 \mu \mathrm{g} / 100 \mathrm{~g}$, while Smooth Cayenne, Pérola and Vitória cultivars showed lower concentrations, respectively, 2.34; 0.69 and $0.32 \mu \mathrm{g} / 100 \mathrm{~g}$. Ramsaroop and Saulo (2007) also investigated the total carotenoid content for Smooth Cayenne and hybrid cultivars, finding concentrations of 45.43 and $136.26 \mu \mathrm{g} / 100 \mathrm{~g}$, respectively. This hybrid cultivar obtained greater acceptance due to its lower acidity and more yellow color, which is consistent with the total carotenoid content and also with the quantification of $\beta$-carotene, which showed $41.59 \mathrm{mg} / 100 \mathrm{~g}$, against $17.22 \mathrm{~g} / 100 \mathrm{~g}$ of Smooth Cayenne cultivar.

Another important antioxidant compound due to its high bioavailability is vitamin $\mathrm{C}$, which acts by protecting the membrane and low-density lipoproteins from oxidative damage (Gardner et al., 2000). The analyzed cultivars showed vitamin $C$ content ranging from 35.88 to $62.11 \mathrm{mg} / 100 \mathrm{~g}$, and Imperial cultivar showed the highest concentration while Vitória cultivar showed lower content of this compound, with no significant difference in relation to Gomo-de-Mel, IAC Fantástico and Smooth Cayenne cultivars (Table 2). This result was similar to that found by Ramsaroop and Saulo (2007), in which Smooth Cayenne cultivar showed $35 \mathrm{mg} /$ $100 \mathrm{~g}$, and its hybrid $68 \mathrm{mg} / 100 \mathrm{~g}$ Vitamin C. These values are higher than those found in another study with Imperial, Smooth Cayenne, Pérola and Vitória cultivars $(18.30 ; 15.18 ; 21.43$ and $16.17 \mathrm{mg} / 100 \mathrm{~g}$, respectively) (VIANA et al, 2013.) as well as for Thai Phulae and Nanglae cultivars (18.88 and $6.45 \mathrm{mg} /$ $100 \mathrm{~g}$, respectively) (KONGSUWAN et al., 2009).

The antioxidant properties of tropical fruits were investigated and the vitamin $\mathrm{C}$ concentration was determined in orange fruits, with value of $67 \mathrm{mg}$ / $100 \mathrm{~g}$ (LIM, LIM; TEE, 2007). In this study, Imperial cultivar showed promising results, since its vitamin $\mathrm{C}$ content was similar to that found for orange, citrus fruit considered as a reference for vitamin $\mathrm{C}$ content (SILVA et al, 2006;. PADAYATTY et al, 2003).

Phenolic compounds are antioxidants that have greater efficiency in scavenging free radicals, and pineapple is an important source of these constituents (HOSSAIN; RAHMAN, 2011). In this work, the total phenolic content ranged from 71.07 mg gallic acid / $100 \mathrm{~g}$ in Smooth Cayenne cultivar to $126.95 \mathrm{mg}$ gallic acid / $100 \mathrm{~g}$ in Imperial cultivar (Table 2). Martínez et al. (2012) analyzed pineapple by-products (mainly core and shell) and found total phenolic content similar to that of Imperial cultivar (129 mg gallic acid / 100 g), while Kongsuwan et al. (2009) showed lower total phenolic content for Thai Phulae and Nanglae cultivars (respectively, 26.20 and $20.28 \mathrm{mg}$ of gallic acid / $100 \mathrm{~g}$ ).

Carotenoids, vitamin $\mathrm{C}$ and phenolic compounds may contribute to the antioxidant activity of fruits and vegetables (HOSSAIN; RAHMAN, 2011). In this paper, it was observed that Imperial cultivar showed higher oxidation inhibition potential (21.75\%), while Vitória cultivar showed the lowest inhibitory potential $(9.92 \%)$ (Table 2$)$. This result is in agreement with other results, since Imperial cultivar showed higher vitamin $\mathrm{C}$ and phenolic compounds content and significant carotenoid content, highlighting the $\alpha$-carotene, cryptoxanthin and $\beta$ - carotene levels. Moreover, among cultivars studied in this work, Vitoria showed the lowest concentrations of vitamin $\mathrm{C}$, phenolic compounds and carotenoids, except for zeaxanthin and $\alpha$-carotene, which, despite showing very low levels for this cultivar, were not detected in Pérola cultivar. 
TABLE 1- Average value of color parameters analyzed for fruits of different pineapple cultivars.

\begin{tabular}{lccc}
\hline Cultivar & $\mathbf{L}^{*}$ & $\mathbf{a}^{*}$ & $\mathbf{b}^{*}$ \\
\hline Imperial & $77.79^{\mathrm{a}} \pm 3.47$ & $-2.79^{\mathrm{a}} \pm 0.38$ & $23.04^{\mathrm{b}} \pm 5.65$ \\
IAC Fantástico & $72.27^{\mathrm{b}} \pm 0.80$ & $-3.37^{\mathrm{a}} \pm 0.22$ & $21.84^{\mathrm{b}} \pm 2.75$ \\
Pérola & $74.69^{\mathrm{b}} \pm 1.87$ & $-1.85^{\mathrm{a}} \pm 0.52$ & $12.69^{\mathrm{c}} \pm 1.94$ \\
Vitória & $72.80^{\mathrm{b}} \pm 2.34$ & $-1.31^{\mathrm{a}} \pm 0.18$ & $12.05^{\mathrm{c}} \pm 1.10$ \\
Gomo-de-Mel & $65.96^{\mathrm{c}} \pm 2.05$ & $-2.95^{\mathrm{a}} \pm 0.20$ & $28.95^{\mathrm{a}} \pm 3.54$ \\
Smooth Cayenne & $74.40^{\mathrm{b}} \pm 0.89$ & $-3.08^{\mathrm{a}} \pm 0.31$ & $20.78^{\mathrm{b}} \pm 1.19$ \\
\hline
\end{tabular}

Values represent mean $\pm \mathrm{SD}$, where $\mathrm{n}=4$. Different letters in the column indicate significant differences $(\mathrm{P}<0.05)$ among cultivars.

TABLE 2 - Vitamin C, phenolic compounds content and antioxidant activity of fruits of different pineapple cultivars.

\begin{tabular}{lccc}
\hline Cultivar & Vitamin C $(\mathbf{m g} / \mathbf{1 0 0 g})$ & $\begin{array}{c}\text { Phenolic compounds } \\
(\mathbf{m g} \text { gallic acid/100g) }\end{array}$ & $\begin{array}{c}\text { Antioxidant } \\
\text { activity } \\
\text { (\% inhibition) }\end{array}$ \\
\hline Imperial & $62.11^{\mathrm{a}} \pm 9.49$ & $126.95^{\mathrm{a}} \pm 7.51$ & $21.75^{\mathrm{a}} \pm 2.06$ \\
Pérola & $49.79^{\mathrm{b}} \pm 6.60$ & $84.90^{\mathrm{c}} \pm 14.74$ & $17.18^{\mathrm{b}} \pm 4.49$ \\
IAC Fantástico & $43.72^{\mathrm{c}} \pm 4.83$ & $89.01^{\mathrm{c}} \pm 12.82$ & $13.29^{\mathrm{c}} \pm 0.64$ \\
Smooth Cayenne & $42.31^{\mathrm{c}} \pm 2.30$ & $71.07^{\mathrm{c}} \pm 1.20$ & $12.96^{\mathrm{c}} \pm 2.33$ \\
Gomo-de-mel & $36.74^{\mathrm{c}} \pm 1.62$ & $109.60^{\mathrm{b}} \pm 10.78$ & $13.55^{\mathrm{c}} \pm 2.16$ \\
Vitória & $35.88^{\mathrm{c}} \pm 2.25$ & $74.09^{\mathrm{c}} \pm 7.91$ & $9.92^{\mathrm{c}} \pm 0.11$ \\
\hline
\end{tabular}

Values represent mean $\pm \mathrm{SD}$, where $\mathrm{n}=4$. Different letters in the column indicate significant differences $(\mathrm{P}<0.05)$ among cultivars.

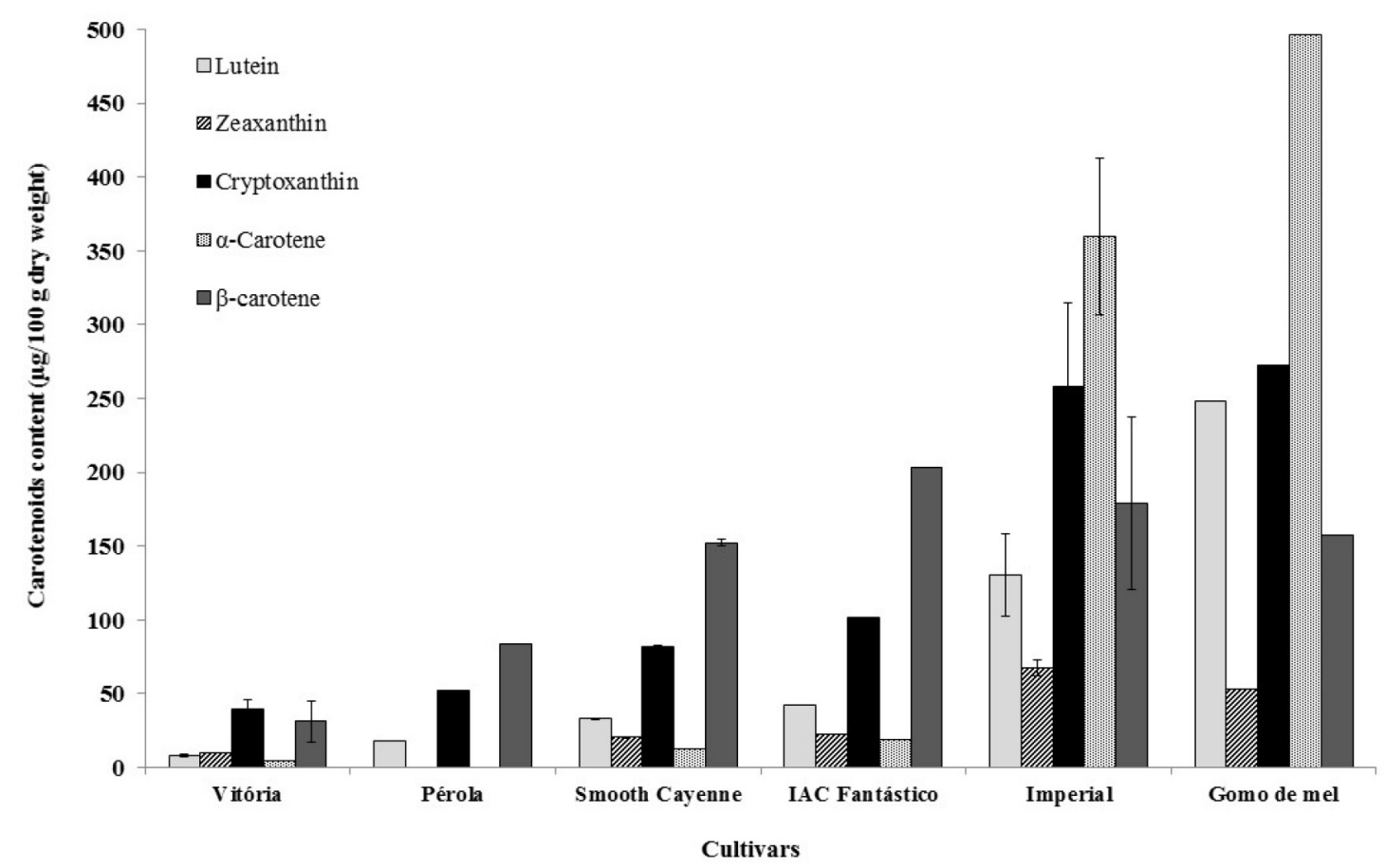

FIGURE 1- Quantification of carotenoids by HPLC in fruit pulp of different pineapple cultivars ( $\mathrm{g} / 100 \mathrm{~g}$ dry weight). 


\section{CONCLUSION}

Gomo-de-Mel and Imperial cultivars showed higher concentrations of carotenoids and phenolic compounds. Imperial cultivar also showed higher levels of vitamin $\mathrm{C}$ and increased antioxidant potential. Thus, it could be inferred that these cultivars stand out due to their high content of bioactive compounds.

\section{ACKNOWLEDGMENTS}

The authors would like to thank FAPEMIG, $\mathrm{CNPq}$ and CAPES for the financial support.

\section{REFERENCES}

AOAC. Official methods of analysis of the Association Analytical Chemists. $18^{\text {th }}$ ed. Gaithersburg, 2005.

BENÍTEZ, S.; CHIUMENTI, M.; SEPULCRE, F.; ACHAERANDIO, I.; PUJOLÁ, M. Modeling the effect of storage temperature on the respiration rate and texture of fresh cut pineapple. Journal of Food Engineering, New York, v.113, n.4, p.527-533, 2012.

BERILLI, S.S.; ALMEIDA, S.B.; CARVALHO, A.J.C.; FREITAS, S.J.; BERILLI, A.P.C.G.; SANTOS, P.C. Avaliação sensorial dos frutos de cultivares de abacaxi para consumo in natura. Revista Brasileira de Fruticultura, Jaboticabal, v.33, p.592-598, 2011. Volume Especial.

BRITO, C.A.K.; SIQUEIRA, P.B.; PIO, T.F.; BOLINI, H.M.A.; SATO, H.H. Caracterização físico-química, enzimática e aceitação sensorial de três cultivares de abacaxi. Ponta Grossa. Revista Brasileira de Tecnologia Agroindustrial, Ponta Grossa, v.2, n.2, p.1-14, 2008.

CHAROENSIRI, R.; KONGKACHUICHA, R.; SUKNICOM, S.; SUNGPUAG, P.Betacarotene, lycopene, and alpha-tocopherol contents of selected Thai fruits. Food Chemistry, Berlin, v.113, p.202$207,2009$.

CUNHA, G.A.P.; CABRAL, J.R.S.; MATOS, A.P.; CALDAS, R.C. Avaliação de genótipos de abacaxi resistentes à fusariose em coração de Maria, Bahia. Magistra, Cruz Almas, v.19, n.3, p.219-223, 2007.
GARDNER, P.T.; WHITE, T.A.C.; MCPHAIL, D.B.; DUTHIE, G.G. The relative contributions of vitamin $\mathrm{C}$, carotenoids and phenolics to the antioxidant potential of fruit juices. Food Chemistry, Berlin, p.68, p.471-474, 2000.

HOSSAIN, M.A.; RAHMAN, S.M.M. Total phenolics, flavonoids and antioxidant activity of tropical fruit pineapple. Food Research International, New York, v.44, p.672-676, 2011.

IAC- Instituto Agronômico de Campinas. São Paulo lança cultivar de abacaxi IAC Fantástico para substituir cultivares em uso no Brasil. 2010. Disponível em: $<$ http://www.iac.sp.gov.br/conteúdo noticias pop.asp?id=606>. Acesso em: 10 out. 2012.

INCAPER. Nova cultivar de abacaxi resistente à fusariose. Vitória, 2006. (Documento, 148).

K ONGSUWAN, A., SUTHILUK, P., THEPPAKORN, T., SRILAONG, V.; SETHA, S. Bioactive compounds and antioxidant capacity of phulae and nanglae pineapple. Asian Journal of Food and Agro-Industry, Bangkok, v.2, n.1, p.4450, 2009. Special Issue

LARRAURI, J.A.; RUPÉREZ, P.; SAURACALIXTO, F. Effect of drying temperature on the stability of polyphenols and antioxidant activity of red grape pomace peels. Journal of Agricultural and Food Chemistry, Washington, v.45, p.13901393, 1997.

LIM, Y.Y.; LIM, T.T.; TEE, J.J. Antioxidant properties of several tropical fruits: a comparative study. Food Chemistry, Berlin, v.103, n. 3, p.10031008, 2007.

MAPA. Novo híbrido resistente à fusariose é lançado na Paraíba. Brasília: Embrapa, 2004. Disponível em: $\leq$ http://www.embrapa.gov.br/imprensa/ noticias/2003/maio/bn.2004-11-25.1029961427/>.

Acesso em: 10 out. 2012.

MARTÍNEZ, R.; TORRES, P.; MENESES, M.A.; FIGUEROA, J.G.; PÉREZ-ÁLVAREZ, J.A.; VIUDA-MARTOS, M. Chemical, technological and in vitro antioxidant properties of mango, guava, pineapple and passion fruit dietary fibre concentrate. Food Chemistry, Berlin, v.135, n.3, p.1520-1526, 2012. 
MERCADANTE, A.Z.; RODRIGUEZ-AMAYA, D.B. Effects of ripening, cultivar differences, and processing on the carotenoid composition of mango. Journal of Agriculture and Food Chemistry, Washington, v.46, p.128-130, 1998.

NACZK, M.; SHAHIDI, F. Extractions and analysis of phenolics in food. Journal of Chromatography A, Amsterdam, v.1054, n.1/2, p.95- 111, 2004.

PADAYATTY, S.J.; KATZ, A., WANG, Y.; ECK, P.; KWON, O.; LEE, J.H.; CHEN, S.; CORPE, C.; DUTTA, A.; DUTTA, S.K.; LEVINE, M. Vitamin $\mathrm{C}$ as an antioxidant: evaluation of its role in disease prevention. Journal of the American College of Nutrition, New York, v.22, p.18-35, 2003.

PAULL, R.; CHEN, C. Postharvest Physiology, Handling and Storage of Pineapple. In: BARTHOLOMEW, D.; PAULL, R.; ROHRBACH, K.G. (Ed.). The pineapple: botany, production and uses. Wallingford: CABI Publishing, 2003. p.253265.

RAMALHO, L.A.; MASCHERONI, R.H. Quality evaluation of pineapple fruit during drying process. Food and Bioproducts Processing, Amsterdam, v.90, p.275-283, 2012.

RAMOS, M.J.M; MONNREAT, G.R.P.; CARVALHO, A.J.C. Qualidade sensorial dos frutos do abacaxizeiro 'Imperial' cultivado em deficiência de macronutrientes e de Boro. Revista Brasileira de Fruticultura, Jaboticabal, v.32, n. 3, p.692-699, 2010.

RAMSAROOP, R.E.S.; SAULO, A.A. Comparative consumer and physicochemical analysis of del monte hawai 1 gold and Smooth Cayenne pineapple cultivars. Journal of Food Quality, Trumbull, v.30, p.135-159, 2007.

R CORE TEAM (2013). R: A language and environment for statistical computing, $R$ Foundation for Statistical Computing, Vienna, Austria. ISBN 3-900051-07-0, http://www.R-project. org/

RUFINO, M.S.M.; ALVES, R.E.; BRITO, E.S.; MORAIS, S.M.; SAMPAIO, C.G.; PÉREZJIMÉNEZ, J.; SAURA-CALIXTO, F. Metodologia científica: determinação da atividade antioxidante total em frutas pela captura do radical livre DPPH. Fortaleza: Embrapa, 2007. (Comunicado técnico)
SETIAWAN, B.; SULAEMAN, A.; GIRAUD, D.W.; DRISKELL, J.A. Carotenoid content of selected undonesian fruits. Journal of Food Composition and Analysis, London, v.14, p.169-176, 2001.

SIES, H., STAHL, W. Vitamins E and C, $\beta$-carotene, and other carotenoids as antioxidants. American Journal of Clinical Nutrition, Bethesda, v.62, n. 6, p.1315-1321, 1995.

SILVA, P.T.; LOPES, M.L.M.; VALENTEMESQUITA, V.L. Efeito de diferentes processamentos sobre o teor de ácido ascórbico em suco de laranja utilizado na elaboração de bolo, pudim e geleia. Ciência e Tecnologia de Alimentos, Campinas, v.26, n. 3, p.678-682, 2006.

STROHECKER, R.; HENNING, H.M. Analisis de vitaminas: métodos comprobados. Madrid: Paz Montalvo, 1967. 428p.

USBERTI FILHO, J.A.; SIQUEIRA, W.J.; SPIRONELLO, A.; TANAKA, M.A.S.; SIGRIST, J.M.M.; MARTINS, A.L.M.; BORTOLETTO, N.; TSUHAKO AT.; GUSHIKEN, A. IAC Gomode-mel. Campinas: Instituto Agronômico de Campinas, 1999.

VENTURA, J.A.; COSTA H.; CAETANO, L.C.S. Abacaxi 'Vitória': uma cultivar resistente à fusariose. Revista Brasileira de Fruticultura, Jaboticabal, v.31, n. 4, p.931-1233, 2009.

VIANA, E.S.; REIS, R.C.; JESUS, J.L.; JUNGHANS, D.T.; SOUZA, F.V.D. Caracterização físico-química de novos híbridos de abacaxi resistentes à fusariose. Ciência Rural, Santa Maria, v.43, n.7, p.11551161, 2013.

WATERHOUSE A. L. Polyphenolics: Determination of total phenolics. In: WROLSTAD, R.E. (Ed.). Currents protocols in food analytical chemistry. New York: John Wiley; 2002.p.1-4.

ZANATTA, C.F.; MERCADANTE, A.Z. Carotenoid composition from the Brazilian tropical fruit camucamu (Myrciaria dubia). Food Chemistry, Berlin, v.101, p.1526-1532, 2007.

ZEB, A.; MEHMOOD, S. Carotenoids contents from various sources and their potential health applications. Pakistan Journal of Nutrition, Faisalabad, v.3, n. 3, p.199-204, 2004. 